\title{
PERFORMANCE STUDIES ON DOWNDRAFT GASIFIER WITH BIOMASS ENERGY SOURCES AVAILABLE IN REMOTE VILLAGES
}

\author{
${ }^{1}$ ChristusJeya Singh, V., ${ }^{2}$ S. Joseph Sekhar and ${ }^{3}$ K. Thyagarajan \\ ${ }^{1,2}$ St.Xavier's Catholic College of Engineering, Chunkankadai, Kanyakumari, Tamilnadu, India \\ ${ }^{3}$ Hindustan College of Engineering, Kerala, India
}

Received 2014-01-01; Revised 2014-01-23; Accepted 2014-02-04

\begin{abstract}
Increasing global concern over the environmental issues and depletion of fossil fuels, significant interest has been shown by the researchers to develop alternate energy technologies like biomass, biogas, solar to meet the future energy demand. The prediction of the performance of different biomass energy sources in gasifiers is needed for the implementation of this technology to fulfil the need of decentralized heat and power applications, relevant to remote villages. This study presents the theoretical and experimental studies conducted on a $50 \mathrm{~kW}$ downdraft biomass gasifier with various biomass materials such as wood, coconut shell, rubber seed kernel and coir pith which are generally available in villages. Two-zone kinetic equilibrium model approach is used to predict the composition and temperature of the producer gas. The influence of equivalence ratio on the reaction temperature, quality of producer gas and gasifier conversion efficiency are discussed. The experimental and theoretical studies show that the rubber seed kernel can be effectively used as a feedstock of the biomass gasifier to meet the rural energy demand.
\end{abstract}

Keywords: Kinetic Model, Equivalence Ratio, Gasifier, Biomass, Conversion Efficiency

\section{INTRODUCTION}

The energy from biomass is a most viable technology to be used in domestic and commercial applications. Different types of biomass materials are available in many parts of the world as residues from the primary use of other applications. In India, the energy from biomass dominates the rural energy consumption (Ravindranath et al., 2005). Considering the concern over the importance and potential of biomass gasification process worldwide and the rural energy demand, it is necessary to model the gasification process and predict the quality of producer gas to meet the requirements of different applications. Among the gasification technologies, the downdraft gasification has an increased interest among the researchers worldwide due to its suitability to produce mechanical and electrical power at affordable price even in small scale applications (Erlich and Fransson, 2011). The downdraft gasifier is comparatively cheaper and it produces relatively low tar $(\sim 0.1 \%)$ during gasification (Giltrap et al., 2003). The simulation of gasifier may be carried out by thermodynamic equilibrium modelling, kinetic modelling, numerical modelling and artificial neural network (Budhathoki, 2013). The important parameters such as moisture content, equivalence ratio, producer gas composition and heating value of gas have been analysed in chemical equilibrium approach (Pitchandi, 2012; Melgar et al., 2007). It was observed that the calorific value of the producer gas decreases with increase in moisture content and the gasification temperature (Zainal et al., 2001). The model developed based on the minimization of Gibbs free energy is found good to simulate the gasification process above $1500 \mathrm{~K}$ (Altafini et al., 2003). Moreover, correction coefficient has been used to improve the accuracy of the equilibrium model (Jarungthammachote and Dutta, 2007).

Corresponding Author: ChristusJeya Singh, V., St.Xavier's Catholic College of Engineering, Chunkankadai, Kanyakumari, Tamilnadu, India 
Kinetic models are developed to predict the behaviour of reduction zone. Wang and Kinoshita (1993) observed that the chemical reactions proceed very rapidly during the first 20 s of the residence time and the increase in char particle size would decrease the surface reaction rate (Wang and Kinoshita, 1993). A kinetic model incorporating char reactivity factor has been developed for analysing composition of gas along the reduction zone of a cylindrical downdraft biomass gasifier, in which the concentration of methane was over-predicted. A model has been developed based on thermodynamic and chemical kinetics to find out the temperature and rate of feedstock consumption in the pyrolysis zone (Sharma, 2008a; Kaosol and Sohgrathok, 2013). It is also showed that the critical char bed length for complete formation of product gas could be $25 \mathrm{~cm}$ (Sharma, 2008b; Malakahmad et al., 2013).

The experimental works have been carried out (Singh et al., 2006; Pengmei et al., 2008; Sheth and Babu, 2009; Ahmed and Gupta, 2009; Jaojaruek et al., 2011; Jayah et al., 2003) to predict the influence of different factors like moisture content, equivalence ratio, reaction temperature, heating value of biomass, on the performance of downdraft biomass gasifier. The conversion efficiency, temperature across the gasifier, producer gas composition, heating value of gas, have been reported for downdraft gasifiers working on fuels like cashew nut shell, pine wood, wheat straw, kiker wood, waste wood, food waste, card board, paper waste, pellets of palm oil residue. The numerical and experimental study conducted to analyse the behaviour of reduction zone (Jayah et al., 2003) shows that the conversion efficiency of the gasifier, with wood as fuel, decreases as the throat angle increases. Moreover, the optimum value for the reduction zone length has been reported as $22 \mathrm{~cm}$. In air gasification, the gas quality or the gas composition including tar and quantity varies widely depending on the gasifier configuration, chemical composition of the feedstock, moisture content, size, density and equivalence ratio (Sheth and Babu, 2010). Therefore specific studies are needed to predict the performance of gasifiers when there is a variation in the above said parameters.

In this study, analytical and experimental methods have been used to study the performance of downdraft gasifier with biomass materials such as wood, coconut shell, rubber seed kernel and coir pith, which are available abundantly in southern part of India. The samples of biomass materials have been collected from various regions like places near forest, coconut tree farms, sea shore and villages in remote areas. Experimental study was also conducted to compare the performance of gasifier with the above said biomass energy sources.

\section{MATERIALS AND METHODS}

The schematic diagram of the gasifier model used in this study is shown in Fig. 1. The pyrolysis and oxidization zones are defined as zone- 1 and it is modelled based on thermodynamic equilibrium of species. The reduction zone has been defined as zone2 and it is modelled based on chemical kinetics of char reactions. In order to implement the equilibrium analysis the assumptions used in this analysis are steady state gas flow inside the gasifier, adiabatic wall, infinite residence for the reactions to take place, uniform species temperature at each level of gasification, negligible amount of tar or unburnt hydrocarbon in the exhaust and major species in the product gases are $\mathrm{CO}, \mathrm{CO}_{2}, \mathrm{H}_{2}, \mathrm{CH}_{4}$ and $\mathrm{N}_{2}$.

\subsection{Zone-1 (Pyrolysis and Oxidation)}

While using a biomass, the global reaction of gasification process can be written as Equation (1):

$$
\begin{aligned}
& \mathrm{CH}_{1} \mathrm{O}_{\mathrm{p}} \mathrm{N}_{\mathrm{q}}+\mathrm{M}_{\mathrm{w}} \mathrm{H}_{2} \mathrm{O}+\mathrm{X}_{\mathrm{g}}\left(\mathrm{O}_{2}+3.76 \mathrm{~N}_{2}\right) \\
& \rightarrow \mathrm{x}_{1} \mathrm{CO}+\mathrm{x}_{2} \mathrm{H}_{2}+\mathrm{x}_{3} \mathrm{CO}_{2}+\mathrm{x}_{4} \mathrm{H}_{2} \mathrm{O}+\mathrm{CH}_{4}+\mathrm{x}_{6} \mathrm{~N}_{2}+\mathrm{x}_{7} \mathrm{C}
\end{aligned}
$$

where, $1, \mathrm{p}$ and $\mathrm{q}$ are the number of atoms of hydrogen, oxygen and nitrogen per number of atom of carbon in the biomass and $\mathrm{x}_{1}$ to $\mathrm{x}_{7}$ are the number of moles of species.

The representative chemical formula $\left(\mathrm{CH}_{\mathrm{l}} \mathrm{O}_{\mathrm{p}} \mathrm{N}_{\mathrm{q}}\right)$ of different biomasses is derived from their ultimate analysis, using the generalized procedure (Melgar et al., 2007). The equations used for calculating the number of moles of oxygen in air $\left(\mathrm{X}_{\mathrm{g}}\right)$ and the number of moles of moisture $\left(\mathrm{M}_{\mathrm{w}}\right)$ have been taken from published literature (Prokash et al., 2010; Puah et al., 2013).

The ultimate analysis results of the various levels of feedstock materials are shown in the below Table 1. The higher heating values of the feedstock materials are calculated using the Friedl's equation (Vaezi et al., 2008). The water gas shift and Methanationreactions take place in zone-1are Equation (2 and 3):

$\mathrm{CO}+\mathrm{H}_{2} \mathrm{O} \Leftrightarrow \mathrm{CO}_{2}+\mathrm{H}_{2}$

$\mathrm{C}+2 \mathrm{H}_{2} \Leftrightarrow \mathrm{CH}_{4}$ 


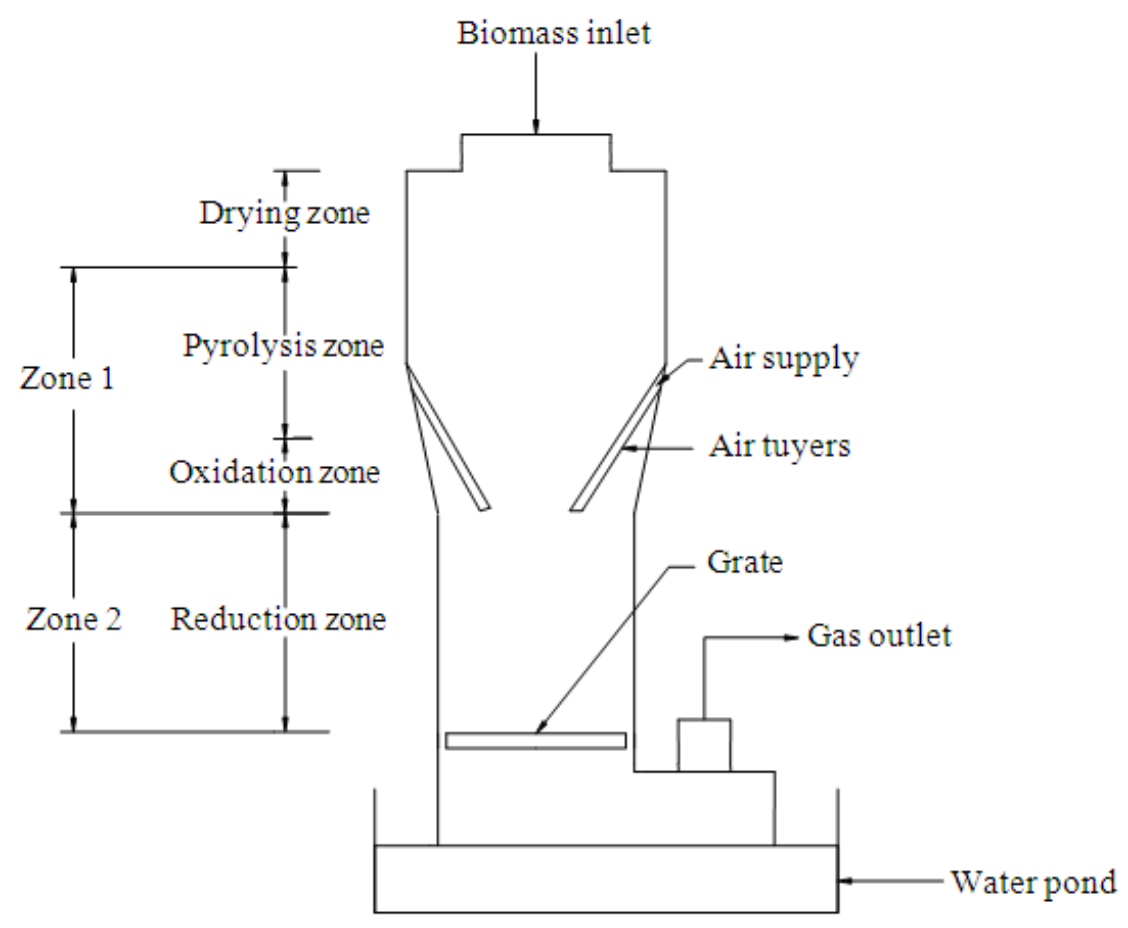

Fig. 1. Schematic of downdraft gasifier

Table 1. Ultimate analysis results of feedstock materials (DAF Basis)

\begin{tabular}{llllll}
\hline & $\mathrm{C}$ & $\mathrm{H}$ & $\mathrm{O}$ & $\mathrm{N}$ & $\mathrm{S}$ \\
Feedstock & \% Wt. & \% Wt. & \% Wt. & \% Wt. & \% Wt. \\
\hline Wood waste & 45.00 & 6.28 & 40.51 & 0.42 & 0.057 \\
Coconut shell & 50.20 & 5.70 & 43.40 & 0.00 & 0.000 \\
Rubber seed kernel & 43.21 & 6.00 & 50.25 & 0.55 & 0.000 \\
Coir Pith & 44.00 & 4.70 & 43.40 & 0.70 & 0.000 \\
\hline
\end{tabular}

The equilibrium constants $\left(\mathrm{K}_{1}\right.$ and $\left.\mathrm{K}_{2}\right)$ for these reactions depend on the temperature, partial pressures and the moles of the respective species and they are obtained as follows Equation (4 and 5):

$$
\begin{aligned}
& \mathrm{K}_{1}=\frac{\left(\mathrm{P}_{\mathrm{CO}_{2}} / \mathrm{P}_{\mathrm{O}}\right)\left(\mathrm{P}_{\mathrm{H}_{2}} / \mathrm{P}_{\mathrm{O}}\right)}{\left(\mathrm{P}_{\mathrm{CO}} / \mathrm{P}_{\mathrm{O}}\right)}=\frac{\mathrm{x}_{2} \mathrm{x}_{3}}{\mathrm{x}_{1} \mathrm{x}_{4}} \\
& \mathrm{~K}_{2}=\frac{\left(\mathrm{P}_{\mathrm{CJ}_{4}} / \mathrm{P}_{\mathrm{O}}\right)}{\left(\mathrm{P}_{\mathrm{H}_{2}} / \mathrm{P}_{\mathrm{O}}\right)^{2}}=\frac{\mathrm{x}_{5}}{\mathrm{x}_{2}^{2}}\left(\sum_{\mathrm{X}=1}^{6} \mathrm{X}_{\mathrm{i}}\right)
\end{aligned}
$$

where, $\mathrm{P}$ is the partial pressure of species.

The values of equilibrium constants $\mathrm{K}_{1}$ and $\mathrm{K}_{2}$ can be calculated from the chan ge in Gibbs free energy between the products and reactants at the temperature of the zone Equation (6 and 7):

$$
\begin{aligned}
& \mathrm{K}_{1}=\exp \left[-\left(\mathrm{g}_{\mathrm{CO}_{2}}+\mathrm{g}_{\mathrm{H}_{2}}-\mathrm{g}_{\mathrm{CO}}-\mathrm{g}_{\mathrm{H}_{2} \mathrm{O}}\right) \mathrm{R} / \mathrm{T}\right] \\
& \mathrm{K}_{2}=\exp \left[-\left(\mathrm{g}_{\mathrm{CH}_{4}}-2 \mathrm{~g}_{\mathrm{H}_{2}}\right) \mathrm{R} / \mathrm{T}\right]
\end{aligned}
$$

where, $\mathrm{R}$ is the universal gas constant in $\mathrm{J} / \mathrm{molK}$.

The values of heat of formation and Gibbs free energy $(g)$ for different gases have been obtained from the JANAF tables (Chase, 1986). The char generated from the gasification process is obtained from the fixed carbon $\left(\mathrm{F}_{\mathrm{C}}\right)$ data of the proximate and it is it is represented as Equation (8):

$\mathrm{x}_{5}+\mathrm{x}_{7}=\frac{\mathrm{F}_{\mathrm{C} 1}}{\mathrm{C}_{1}}+\mathrm{b} \frac{\mathrm{F}_{\mathrm{C} 2}}{\mathrm{C}_{2}}$

The number of moles of respective species, $x_{1}$ to $\mathrm{x}_{7}$, formed in the gasification process has been calculated from equations (Ravindranath et al., 2005; Melgar et al., 2007; Zainal et al., 2001; Jarungthammachote and Dutta, 2007). The species are assumed to be at a uniform temperature at the outlet of zone-1 and have been determined from the energy balance, considering that there is negligible amount of kinetic and potential energy changes Equation (9): 
$\mathrm{Q}_{\text {in }}+\mathrm{Q}_{\text {in }}=\mathrm{Q}_{\text {out }}$

where, $\mathrm{Q}$ is the heat in Joule.

Based on the global reaction given in equation (Ravindranath et al., 2005), the energy balance equation (Jarungthammachote and Dutta, 2007) is expanded as Equation (10):

$$
\begin{aligned}
& \mathrm{Hf}_{1} \mathrm{X}_{\mathrm{g}} \int_{\mathrm{T}_{\mathrm{o}}}^{\mathrm{T}_{\mathrm{a}}} \mathrm{C}_{\mathrm{P}_{\mathrm{o}}} \mathrm{dT}+3.76 \mathrm{X}_{\mathrm{g}} \\
& \int_{\mathrm{T}_{\mathrm{o}}}^{\mathrm{T}_{\mathrm{a}}} \mathrm{C}_{\mathrm{p}_{\mathrm{N}_{2}}} \mathrm{dT}+\mathrm{M}_{\mathrm{w}} \mathrm{h}_{\mathrm{f}_{\mathrm{H} 2 \mathrm{O}}}+\mathrm{Q}_{\text {loss }} \\
& =\sum_{\mathrm{i}=1}^{6} \mathrm{x}_{\mathrm{i}}\left[\mathrm{h}_{\mathrm{fi}}+\int_{\mathrm{T}_{\mathrm{o}}}^{\mathrm{T}} \mathrm{C}_{\mathrm{pi}} \mathrm{dT}\right] \\
& +\mathrm{x}_{7} \mathrm{C}_{\mathrm{pC}}\left(\mathrm{T}-\mathrm{T}_{0}\right)+\mathrm{m}_{\text {ash }} \mathrm{C}_{\text {pash }}\left(\mathrm{T}-\mathrm{T}_{0}\right)
\end{aligned}
$$

where, $\mathrm{H}_{\mathrm{f}}$ and $\mathrm{h}_{\mathrm{f}}$ are the enthalpy of formation of biomass and species respecrively in $\mathrm{J} / \mathrm{mol} . \mathrm{C}_{\mathrm{p}}$ is the molar specific heat of species, $\mathrm{J} / \mathrm{molK}$.

The energy carried out by individual species (CO, $\mathrm{H}_{2}, \mathrm{CO}_{2}, \mathrm{H}_{2} \mathrm{O}, \mathrm{CH}_{4}$ and $\mathrm{N}_{2}$ ), char and ash are considered separately in the above equation. Standard equations are used to find the heats of formation of fuels (Zainal et al., 2001) and specific heats of gaseous species. The specific heats of ash and char are taken as $840 \mathrm{~J} / \mathrm{kgK}$ and $21.86 \mathrm{~J} / \mathrm{molK}$ respectively.

\subsection{Zone-2 (Reduction Zone)}

The species formed in the zone- 1 enter the zone- 2 and undergo the following endothermic reactions to form the final composition of the producer gas Equation (11-14):

$$
\begin{aligned}
& \mathrm{C}+\mathrm{CO}_{2} \Leftrightarrow 2 \mathrm{CO} \\
& \mathrm{C}+\mathrm{H}_{2} \mathrm{O} \Leftrightarrow \mathrm{CO}+\mathrm{H}_{2} \\
& \mathrm{C}+2 \mathrm{H}_{2} \Leftrightarrow \mathrm{CH}_{4} \\
& \mathrm{CH}_{4}+\mathrm{H}_{2} \mathrm{O} \Leftrightarrow \mathrm{CO}+3 \mathrm{H}_{2}
\end{aligned}
$$

The above equations are assumed to be reversible and the rate of reaction is calculated using Arrhenius type kinetic rate equations (Prokash et al., 2010). The mass flow rates of the species $(i=1$ to 7 ) at the inlet of the reduction zone depends on the feed rate of biomass and it is expressed as Equation (15):

$$
\mathrm{X}_{\mathrm{i}}^{0}=\frac{\mathrm{M}_{\mathrm{f}}(0.01 \mathrm{~S})\left(1-0.01 \mathrm{~A}_{1}\right)}{\mathrm{M}_{\mathrm{Cl}}} \mathrm{x}_{\mathrm{i}} ; \mathrm{i}=1-7
$$

where, $\mathrm{A}$ is the percentage ash from the ultimate analysis of dry fuel.

The rate of formation of a species in the following equation, $\mathrm{i}$ at any elemental control volume $\mathrm{k}$ is given by Equation (16):

$\mathrm{X}_{\mathrm{i}}^{\mathrm{k}}=\mathrm{X}_{\mathrm{i}}^{\mathrm{k}-1}+\mathrm{R}_{\mathrm{i}}^{\mathrm{k}} \Delta \mathrm{V}_{\mathrm{k}}$

where, $\Delta \mathrm{V}_{\mathrm{k}}$ is the volume of the kth control volume in $\mathrm{m}^{3}$ and it is obtained by Equation (17):

$\Delta \mathrm{V}_{\mathrm{k}}=\frac{\pi}{3}\left(\mathrm{r}_{\mathrm{k}}^{2}+\mathrm{r}_{\mathrm{k}-1}^{2}+\mathrm{r}_{\mathrm{k}}+\mathrm{r}_{\mathrm{k}} \mathrm{r}_{\mathrm{k}-1}\right) \Delta \mathrm{H}$

The energy balance across any control volume $(\mathrm{k})$ in zone-2 is given as Equation (18):

$$
\begin{aligned}
& \sum_{\mathrm{i}=1}^{6} \mathrm{X}_{\mathrm{i}}^{\mathrm{k}-1}\left(\mathrm{H}_{\mathrm{fi}}+\int_{\mathrm{T}_{\mathrm{o}}}^{\mathrm{T}^{\mathrm{k}-1}} \mathrm{C}_{\mathrm{pi}} \mathrm{dT}\right)+\mathrm{X}_{7}^{\mathrm{k}-1} \mathrm{C}_{\mathrm{pC}}\left(\mathrm{T}^{\mathrm{k}-1}+\mathrm{T}_{\mathrm{o}}\right) \\
& +\mathrm{m}_{\mathrm{ash}} \mathrm{C}_{\mathrm{pash}}\left(\mathrm{T}^{\mathrm{k}-1}-\mathrm{T}_{\mathrm{o}}\right)=\sum_{\mathrm{i}=1}^{6} \mathrm{X}_{\mathrm{i}}^{\mathrm{k}}\left(\mathrm{h}_{\mathrm{fi}}+\int_{\mathrm{T}_{\mathrm{o}}}^{\mathrm{T}^{\mathrm{k}}} \mathrm{C}_{\mathrm{pi}} \mathrm{dT}\right) \\
& +\mathrm{X}_{7}^{\mathrm{k}} \mathrm{C}_{\mathrm{pC}}\left(\mathrm{T}^{\mathrm{k}}-\mathrm{T}_{0}\right)+\mathrm{m}_{\mathrm{ash}} \mathrm{C}_{\mathrm{pash}}\left(\mathrm{T}^{\mathrm{k}}-\mathrm{T}_{0}\right)
\end{aligned}
$$

The temperature of the species within the control volume has been calculated by solving Equation (18). The concentration and temperature of species at the outlet of the last control volume are the conditions of the producer gas at the exit of the gasifier. The quality of the producer gas is evaluated in terms of the production rate of combustible gases, its heating value and temperature. The performance of the gasifier is evaluated in terms of conversion efficiency. The equivalence ratio plays a vital role on the performance of the gasifier and it is also calculated (Shafri et al., 2006; Basu, 2010). If the equivalence ratio is below 0.2 , the conversion efficiency and gas production rate are reduced drastically (Sheth and Babu, 2009). Therefore in the analysis, the equivalence ratio has been taken between 0.2 and 0.45 and the variations in performance parameters are studied.

\subsection{Experimental Setup}

The schematic diagram of the experimental setup consists of an advanced imbert downdraft biomass gasifier of capacity $50 \mathrm{~kW}$, is shown in Fig. 2. A gas analyzer and a gas flow meter are used to check the quality and quantity of the producer gas. Air tuyers inclined at an angle of 450 to the horizontal are placed around the circumference of the oxidation zone. A Utube manometer is used to measure the flow rate. 


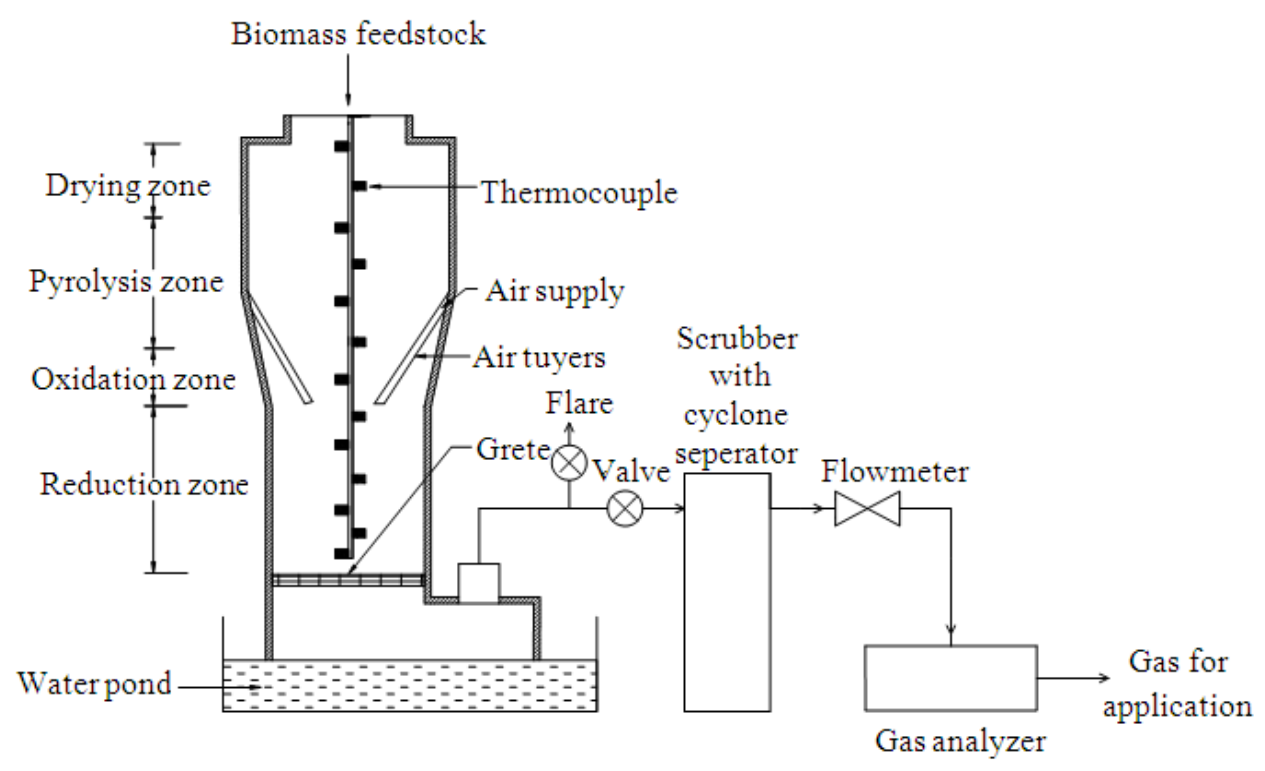

Fig. 2. Schematic diagram of the experimental setup of the downdraft gasifier

Calibrated K-type (chromel-alumel) thermocouples are placed in different location along the various zones. In this gasifier, both biomass feedstock and producer gas move downward as the reaction proceeds. To prevent the leakage of producer gas, a water pond is constructed under the reactor. To calculate the flow rate of feedstock, special arrangement is provided. The mesh used in the grate is selected based on the size of the feedstock material.

\subsection{Experimental Procedure}

The biomass with moisture content less than $5 \%$ was filled in the gasifier. The particle type material (coir pith) was briquetted as per the specification of the grate. A metering rod having a flat plate at the bottom was kept on the feedstock to measure mass flow rate. A data logger was used to record the temperature. An online gas analyser and a gas flow meter were used to measure the quality and quantity of output gas. The air flow rate was measured by manometer of accuracy $\pm 1 \%$. HHV and moisture content of feedstock materials were measured before every loading.

\section{RESULTS}

The results obtained from analytical and experimental studies were analysed and the influence of various energy sources on the performance parameters such as species concentration, gas production rate, higher heating value and conversion efficiency were evaluated. Since equivalence ratio plays a major role on the quality and quantity of producer gas, the variation of performance parameters for the equivalence ratios 0.2 to 0.45 have been analysed. The comparison of species concentration obtained from the present study with the previous works (Jayah et al., 2003) and (Sheth and Babu, 2010) is plotted in Fig. 3.

The quality of the producer gas depends on the concentration of the combustible gases $\left(\mathrm{CO}, \mathrm{H}_{2}\right.$ and $\mathrm{CH}_{4}$ ). Therefore the composition of the combustible gases measured from experimental studies and the composition of all the species of the producer gas obtained from simulation are plotted in Fig. 4a-d. All the plots show that the species concentrations of combustible gases are high when $\phi$ is kept at 0.2. Among all the energy sources the $\mathrm{H}_{2}$ content is maximum in wood and minimum in coir pith. The combustible gas composition for wood, coconut shell and rubber seed kernel are having values close to each other.

The gas production rate is influenced by the equivalence ratio. Therefore it has been analysed in both experimental and simulation studies and plotted in Fig. 5a-d.

The gasifier conversion efficiency is defined as the ratio of energy content of the producer gas to the energy content of the biomass feedstock. The impact of equivalence ratio on conversion efficiency is depicted in Fig. 6a-d. 
ChristusJeya Singh, V. et al. / American Journal of Applied Sciences 11 (4): 611-622, 2014

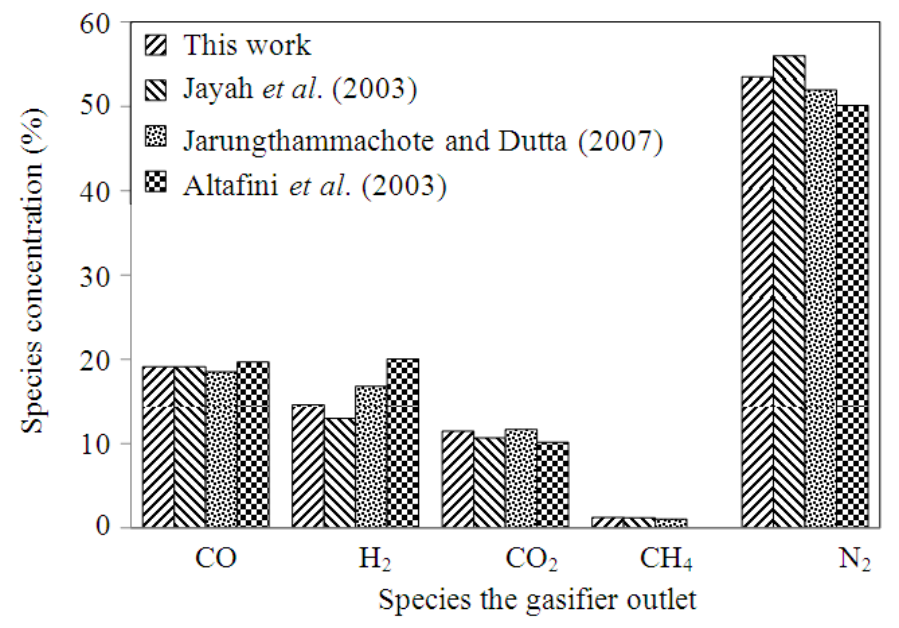

Fig. 3. Comparison of predicted and reported species concentrations at the gasifier outlet

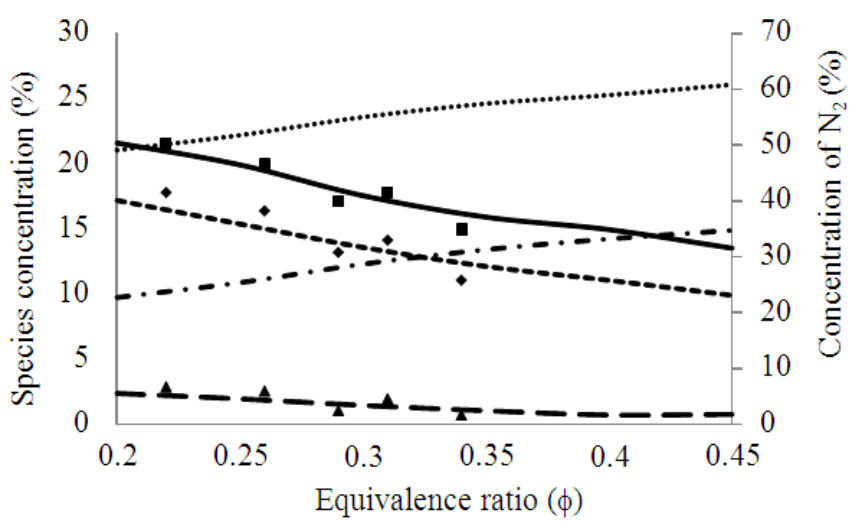

$$
\begin{aligned}
& -\mathrm{CO}(\mathrm{S}) \quad-\cdots \mathrm{H}_{2}(\mathrm{~S}) \quad-\mathrm{CH}_{4}(\mathrm{~S}) \quad \text { S-Simulation } \\
& \text {-. } \mathrm{CO}_{2}(\mathrm{~S}) \quad \mathrm{CO}(\mathrm{E}) \quad \mathrm{H}_{2}(\mathrm{E}) \quad \text { E-Experiment }
\end{aligned}
$$

(a)

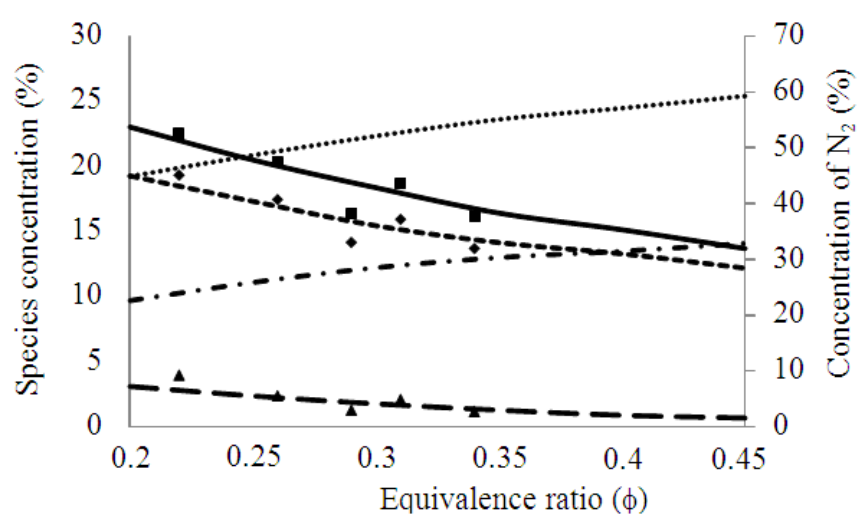

$$
\begin{array}{llll}
-\mathrm{CO}(\mathrm{S}) & -\boldsymbol{\mathrm { H } _ { 2 }}(\mathrm{S}) & -\mathrm{CH}_{4}(\mathrm{~S}) & \text { S-Simulation } \\
-\cdot \mathrm{CO}_{2}(\mathrm{~S}) & -\mathrm{CO}(\mathrm{E}) & -\mathrm{H}_{2}(\mathrm{E}) & \text { E-Experiment }
\end{array}
$$

(b) 
ChristusJeya Singh, V. et al. / American Journal of Applied Sciences 11 (4): 611-622, 2014
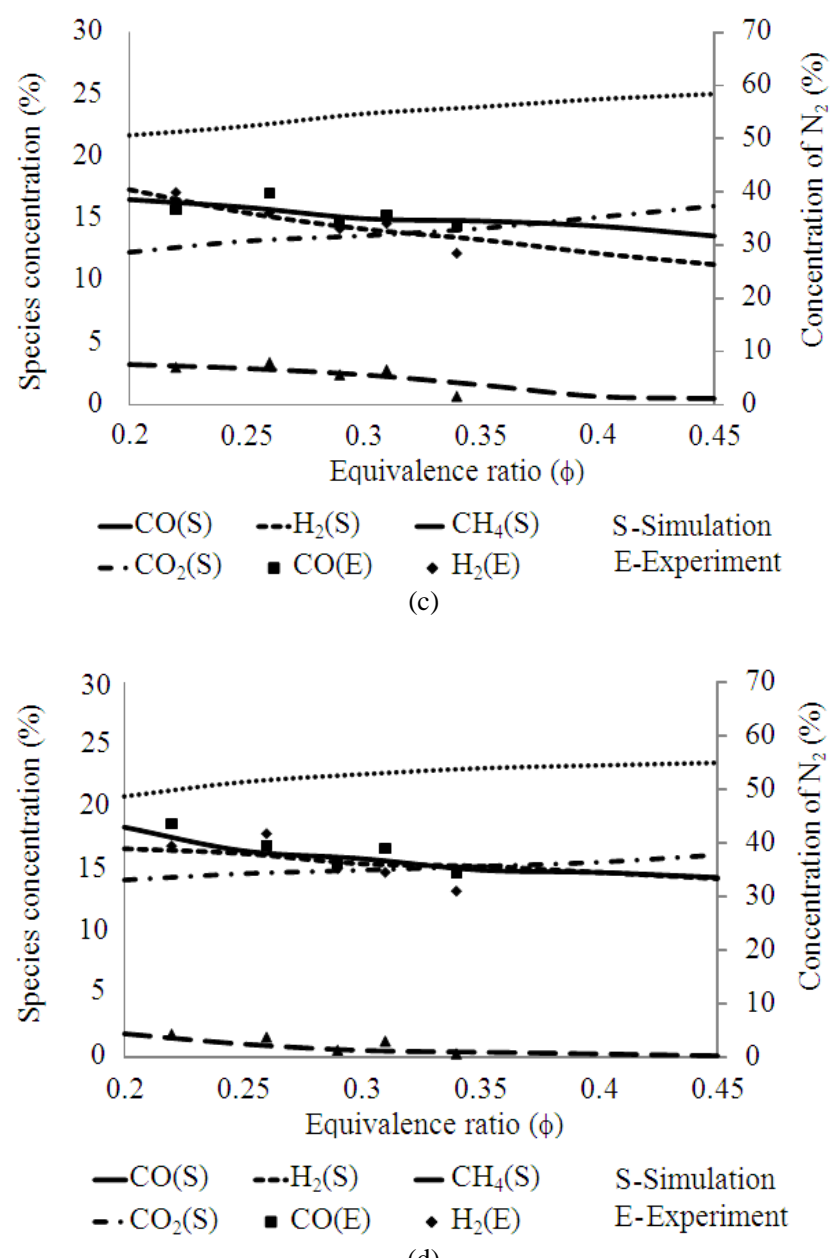

(d)

Fig. 4. Variation of species concentration with $\phi$ for the biomass, (a) coconut shell (b) wood (c) coir pith (d) rubber seed kernel

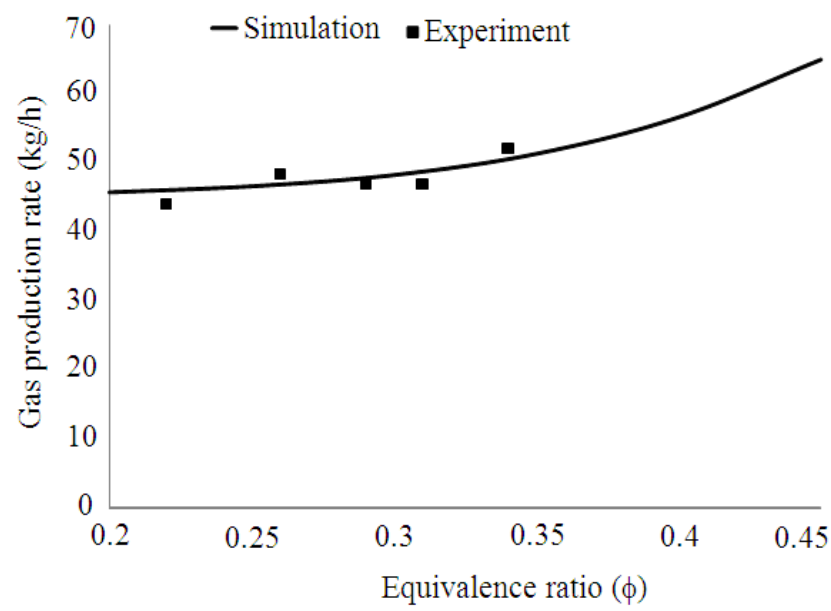

(a) 
ChristusJeya Singh, V. et al. / American Journal of Applied Sciences 11 (4): 611-622, 2014

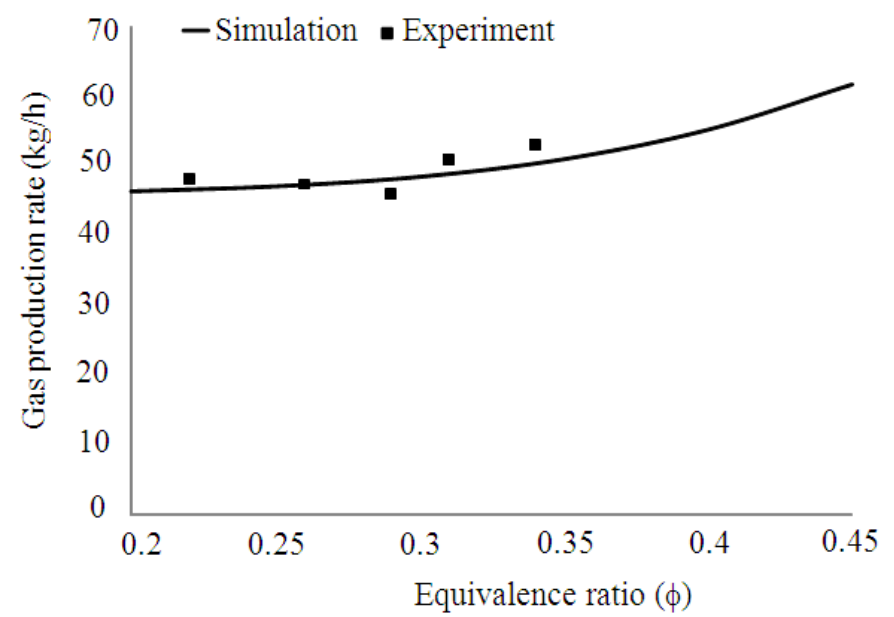

(b)

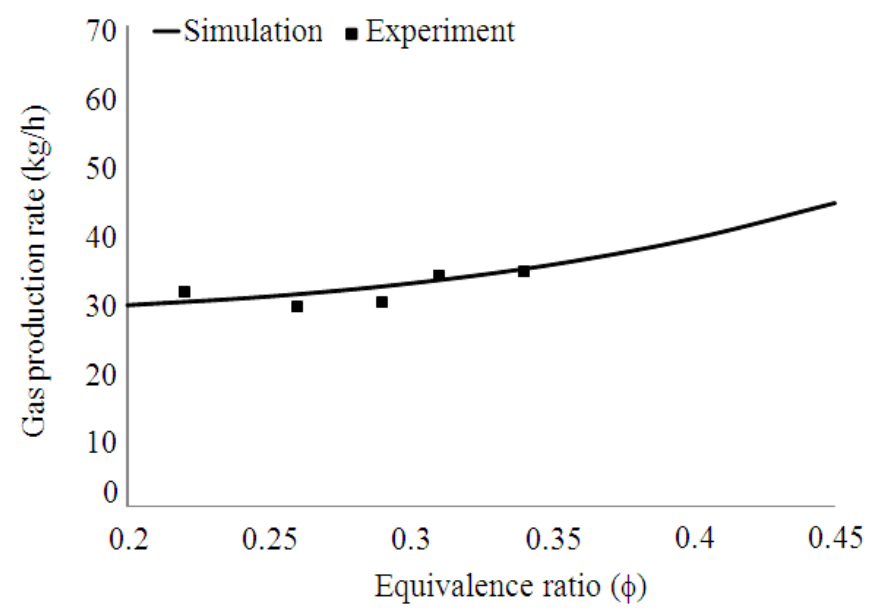

(c)

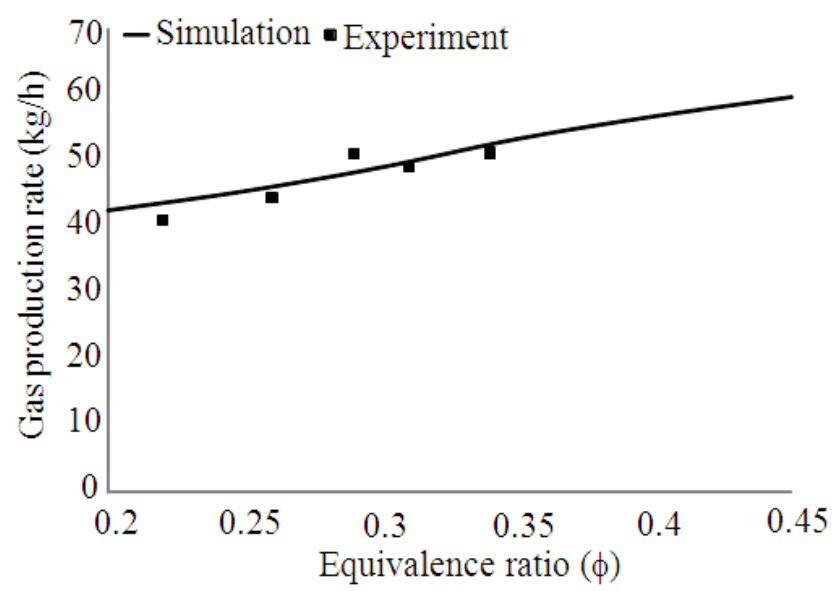

(d)

Fig. 5. Variation of gas production rate with $\phi$ for the biomass, (a) coconut shell (b) wood (c) coir pith (d) rubber seed kernel 
ChristusJeya Singh, V. et al. / American Journal of Applied Sciences 11 (4): 611-622, 2014

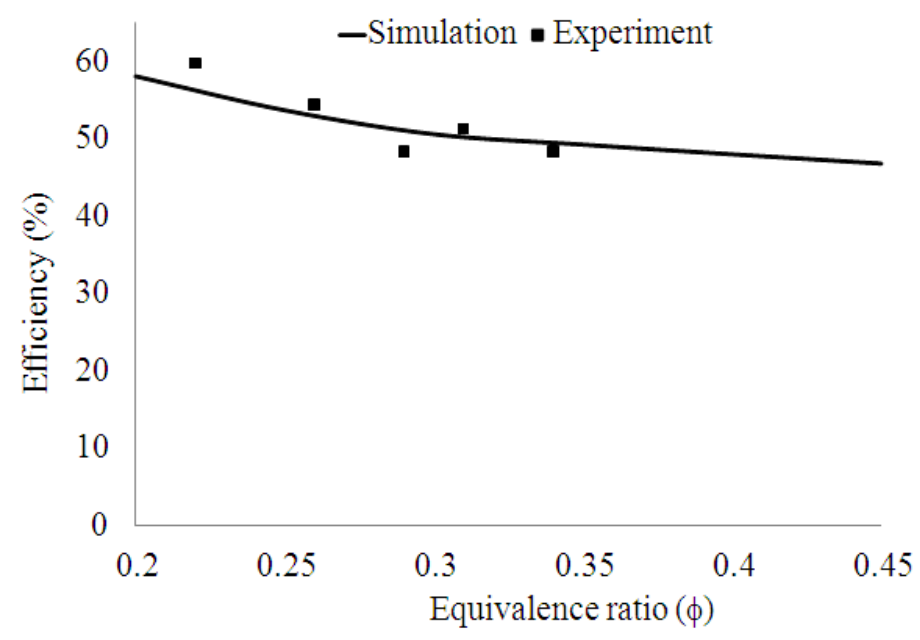

(a)

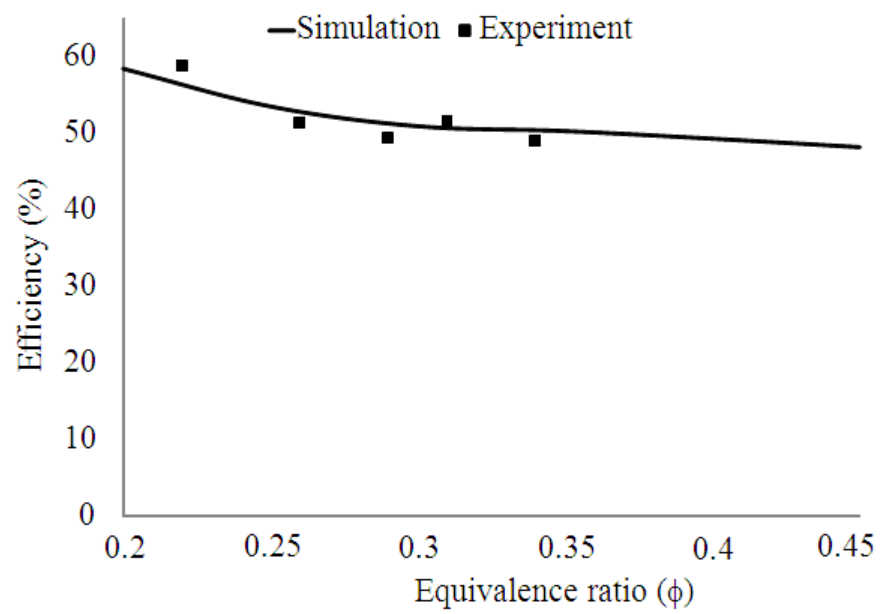

(b)

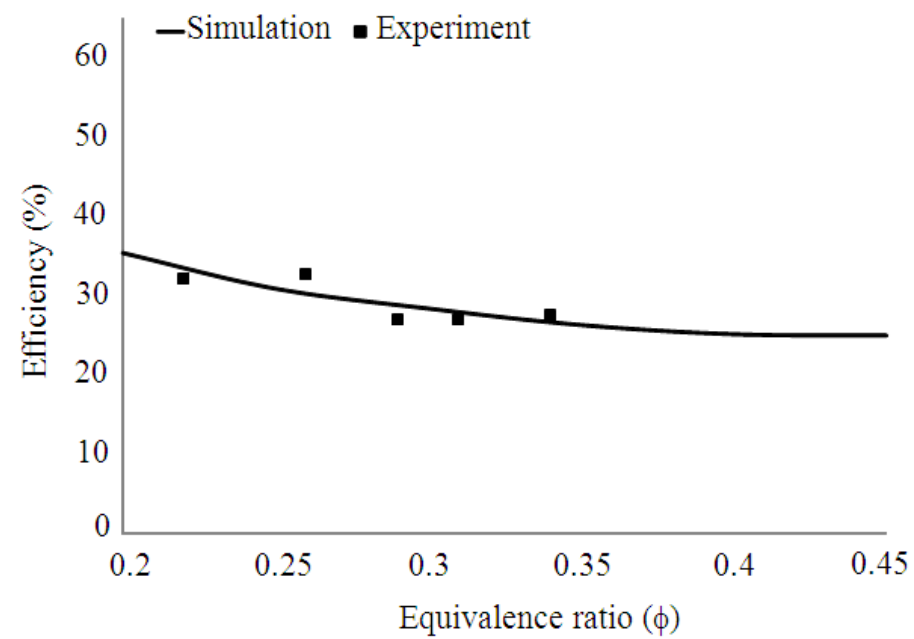

(c) 


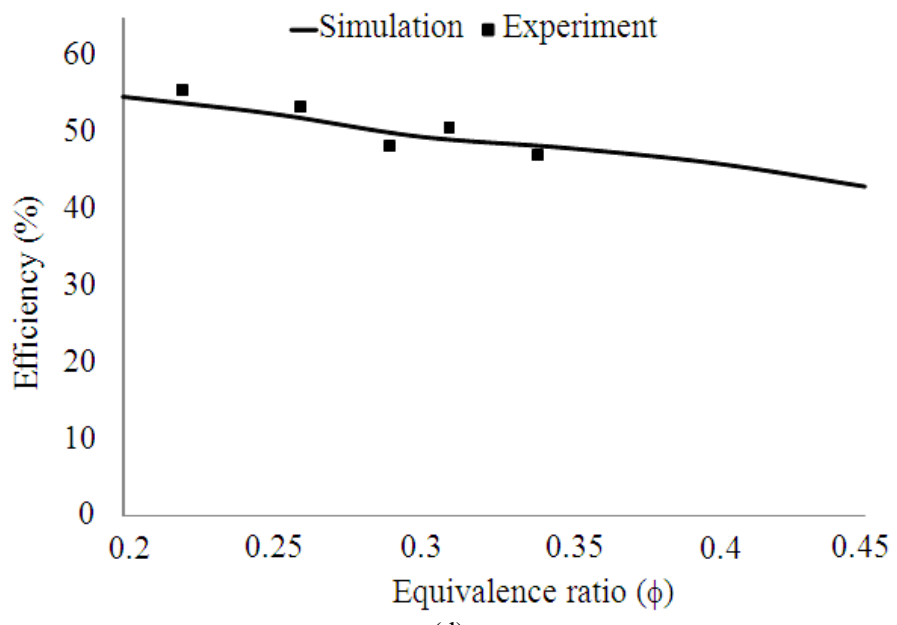

(d)

Fig. 6. Variation of conversion efficiency with $\phi$ for the biomass, (a) coconut shell (b) wood (c) coir pith (d) rubber seed kernel

\section{DISCUSSION}

The deviation of the present result is within $15 \%$, (Fig. 3) as compared to the previous results. Thus the validity of the present approach has been confirmed. Due to the low carbon content and heating value, the composition of combustible species in the producer gas from coir pith is $6-20 \%$ less when compared to other energy sources (Fig. 4a-d). The species concentration obtained from the simulated results is 10 to $15 \%$ deviating from experimental values. This is due to the heat transfer takes place across the gasifier walls and non-uniform flow patterns prevailing inside the gasifier during experimentation.

When $\phi$ increases, the amount of $\mathrm{O}_{2}$ supplied for the specific flow rate of fuel also increases (Fig. 5ad). Due to this, the amount of fuel involved in the combustion process increases and the concentration of combustible gases in the output gas will be reduced.

It is observed that the variation of $\phi$ between 0.2 and 0.3 does not change the gas production rate significantly. However this variation is considerable for the values of $\phi$ between 0.3 and 0.45 due to the quantity of $\mathrm{N}_{2}$ supplied in the inlet air. This will affect the gasifier conversion efficiency, hence it is desirable to use wood chips, coconut shell and rubber seed kernel as energy sources to maintain almost constant gas production rate.

The conversion efficiency is maximum (Fig. 6a-d) when the energy source is having higher heating value. In all the biomass materials a drastic reduction in efficiency is obtained when the equivalence ratio is increased from 0.2 to 0.3 . This is due to the impact of the gas production rate as shown in Fig. 5a-d. In this study, the lowest efficiency is observed for coir pith because of its poor thermophysical properties.

\section{CONCLUSION}

A detailed study has been carried out analytically and experimentally in order to find the feasibility of using various biomass energy sources in an imbert type downdraft gasifier. The performance parameters such as species concentration, gas production rate and gasifier conversion efficiency were analysed and the following conclusions are drawn.

- The HHV of the biomass influences the performance parameters

- All the biomasses have higher conversion efficiency when the equivalence ratio is close to 0.2 . Therefore irrespective of the type of biomass, to obtain high conversion efficiency, the equivalence ratio should be maintained close to 0.2

- Among the four sources, the coir pith shows poor performance. Therefore it can be used when the other biomasses are not available

- Wood and coconut shell shows maximum combustible species concentration and conversion efficiency. Therefore priority should be given to use these materials

- The performance of rubber kernel is lower than wood and coconut shell. Hence this could be used when the other two are in scarcity 
In most of the villages, considered in this study, different biomasses are available and the quantity, size and quality of raw biomasses also vary from place to place. Hence a suitable simulation and experimental study on the mixture of the available biomasses can also be carried out to predict the effective use of this technology in rural villages either for power production or food preservation.

\section{REFERENCES}

Ahmed, I. and A.K. Gupta, 2009. Characteristics of cardboard and paper gasification with $\mathrm{CO}_{2}$. Applied Energy, 86: 2626-2634. DOI: 10.1016/j.apenergy.2009.04.002

Melgar, A., J.F. Perez, H. Laget and A. Horillo, 2007. Thermochemical equilibrium modelling of a gasifying process. Energy Convers. Manage., 48: 59-67. DOI: 10.1016/j.enconman.2006.05.004

Sharma, A.K., 2008a. Equilibrium modeling of global reduction reactions for a downdraft (biomass) gasifier. Energy Conversion Manage., 49: 832-842. DOI: 10.1016/j.enconman.2007.06.025

Sharma, A.K., 2008b. Equilibrium and kinetic modeling of char reduction reactions in a downdraft biomass gasifier: A comparison. Solar Energy, 82: 918-28. DOI: 10.1016/j.solener.2008.03.004

Erlich, C. and TH. Fransson, 2011. Downdraft gasification of pellets made of wood, palm-oil residues respective bagasse: Experimental study. Applied Energy, 88: 899-908. DOI: 10.1016/j.apenergy.2010.08.028

Altafini, C.R., P.R. Wander and R.M. Barreto, 2003. Prediction of the working parameters of a wood waste gasifier through an equilibrium model. Energy Conversion Manage., 44: 2763-2777. DOI: 10.1016/S0196-8904(03)00025-6

Giltrap, D.L., R. McKibbin and G.R.G. Barnes, 2003. A steady state model of gas-char reactions in a downdraft gasifier. Solar Energy, 74: 85-91. DOI: 10.1016/S0038-092X(03)00091-4

Chase, M.W., 1986. JANAF Thermochemical Tables. 3rd Edn., American Chemical Society, Washington, pp: 1856.

Jarungthammachote, S. and A. Dutta, 2007. Thermodynamic equilibrium model and second law analysis of a downdraft waste gasifier. Energy, 32: 1660-1669. DOI: 10.1016/j.energy.2007.01.010
Jayah, T.H., L. Aye, R.J. Fuller and D.F. Stewart, 2003. Computer simulation of a downdraft wood gasifier for tea drying. Biomass Bioenergy, 25: 459-469. DOI: 10.1016/S0961-9534(03)00037-0

Kaosol, T. and N. Sohgrathok, 2013. Enhancement of biogas production potential for anaerobic codigestion of wastewater using decanter cake. Am. J. Agric. Biol. Sci., 7: 494-502. DOI: 10.3844/ajabssp.2012.494.502

Jaojaruek, K., S. Jarungthammachote, M. Kathrina, B. Gratuito and H. Wongsuwan, 2011. Experimental study of wood downdraft gasification for an improved producer gas quality through an innovative two-stage air and premixed air/gas supply approach. Bioresou. Technol., 102: 48344840. PMID: 21292477

Malakahmad, A., S.B. Nasrudin and S.M. Zain, 2013. Anaerobic transformation of biodegradable waste; simultaneous production of energy and fertilizer. Am. J. Environ. Sci., 9: 113-119. DOI: 10.3844/ajessp.2013.113.119

Sheth, P.N. and B.V. Babu, 2009. Experimental studies on producer gas generation from wood waste in a downdraft biomass gasifier. Bioresou. Technol., 100: 3127-3133. DOI: 10.1016/j.biortech.2009.01.024

Sheth, P.N. and B.V. Babu, 2010. Production of hydrogen energy through biomass (waste wood) gasification. Hydrogen Energy, 35: 10803-10810. DOI: 10.1016/j.ijhydene.2010.03.009

Basu, P., 2010. Biomass Gasification and Pyrolysis: Practical Design and Theory. 1st Edn., Academic Press, Burlington, ISBN-10:0080961622, pp: 376.

Pengmei, L., W. Chuangzhi, M. Longlong and Z. Yuan, 2008. A study on the economic efficiency of hydrogen production from biomass residues in China. Renewable Energy, 33: 1874-1879. DOI: 10.1016/j.renene.2007.11.002

Pitchandi, K., 2012. Analysis of biomass based downdraft gasifier using equilibrium model. IJME, 1: 26-34.

Prokash, C.R., A. Datta and N. Chakraborty, 2010. Assessment of cow dung as a supplementary fuel in a downdraft biomass gasifier. Renewable Energy, 35: 379-386. DOI: 10.1016/j.renene.2009.03.022

Puah, C.W., Y.M. Choo and S.H. Ong, 2013. Production of palm oil with methane avoidance at palm oil mill: A case study of cradle-to-gate life cycle assessment. Am. J. Applied Sci., 10: 1351-1355. DOI: 10.3844/ajassp.2013.1351.1355 
Ravindranath, N.H., H.I. Somashekar, M.S. Nagaraja, P. Sudha and G. Sangeetha et al., 2005. Assessment of sustainable non-plantation biomass resources potential for energy in India. Biomass Bioenergy, 29: 178-190. DOI: 10.1016/j.biombioe.2005.03.005

Budhathoki, R., 2013. Three zone equilibrium modeling of downdraft biomass gasification: Equilibrium and finite kinetic approach, Masters Thesis, Department of Chemistry, University of Jyvaskyla.

Vaezi, M., M. Passandideh-Fard, M. Moghiman and M. Charmchi, 2008. Modeling biomass gasification: A new approach to utilize renewable sources of energy. Proceedings of the ASME International Mechanical Engineering Congress and Exposition, Oct. 31-Nov. 6, IEEE Xplore Press Boston, Massachusetts, USA., pp: 927-935. DOI: 10.1115/IMECE2008-68707
Singh, R.N., U. Jena, J.B. Patel and A.M. Sharma, 2006. Feasibility study of cashew nut shells as an open core gasifier feedstock. Renewable Energy, 31: 481487. DOI: 10.1016/j.renene.2005.04.010

Shafri, H.Z., M.A. Salleh, A. Ghiyamat and M.A. Salleh, 2006. Hyperspectral remote sensing of vegetation using red edge position techniques. Am. J. Applied Sci., 3: 1864-1871. DOI: 10.3844/ajassp.2006.1864.1871

Wang, Y. and C.M. Kinoshita, 1993. Kinetic model of biomass gasification. Solar Energy, 51: 19-25. DOI: 10.1016/0038-092X(93)90037-O

Zainal, Z.A., R. Ali, C.H. Lean and K.N. Seetharamu, 2001. Prediction of performance of a downdraft gasifier using equilibrium modeling for different biomass materials. Energy Conversion Manage., 42: 1499-1515. DOI: 10.1016/S0196-8904(00)00078-9 